\title{
Socialization of the Utilization of Seaweed and Diversification of Its Processes as Functional Food in an Effort to Increase the Immune System during the COVID-19 Pandemic
}

\section{Sosialisasi Pemanfaatan Rumput Laut dan Diversifikasi Olahannya Sebagai Pangan Fungsional dalam Usaha Peningkatan Sistem Kekebalan Tubuh di Masa Pandemi COVID-19}

\author{
Warsidah $^{\mathrm{a}}$, Dzul Fadly ${ }^{\mathrm{b} *}$, \& Arman Amran ${ }^{\mathrm{c}}$ \\ ${ }^{a}$ Jurusan Kelautan, Fakultas MIPA, Universitas Tanjungpura, Pontianak, Kalimantan Barat, Indonesia \\ ${ }^{b}$ Program Studi Ilmu dan Teknologi Pangan, Fakultas Pertanian,Universitas Tanjungpura, Pontianak, Kalimantan Barat, Indonesia \\ ${ }^{c}$ Program Studi AgroBisnis, Fakultas Pertanian dan Kehutanan, Universitas Sulawesi Barat, Majene, Sulawesi Barat, Indonesia
}

\begin{abstract}
Seaweed or known as macroalgae, is one of the marine commodities with valuable economic potential for domestic and foreign markets. West Kalimantan, especially on Lemukutan Island, is one of the cultivation centers for Eucheuma cottoni and E.spinosum. The use of seaweed as a functional food in various kinds of preparations has not been implemented optimally. This PKM activity aims to socialize the use and consumption of seaweed and diversify its processing in an effort to improve the immune system, especially during the COVID-19 pandemic. A total of 256 participants stated that they were ready to attend the webinar, which was delivered in an online form distributed by the organizing committee. Socialization activities are carried out online with the material presented related to seaweed and its various preparations and its function as food in improving health status through repair, restoration, or enhancement of the immune system, so it is very important to socialize consumption and utilize this food as a defense agent for the body during pandemic COVID-19 or after. The results of the evaluation of PKM activities through the pretest and posttest shows that the participants' knowledge regarding the material presented has increased from $40-50 \%$ to $80-90 \%$, for that it is still expected that there will be similar activities with a wider target object in West Kalimantan which can improve the welfare of society in general.
\end{abstract}

\begin{abstract}
Abstrak
Rumput laut atau dikenal sebagai makroalga merupakan salah satu komoditas perairan laut yang memiliki potensi ekonomi yang sangat bernilai baik untuk pasaran domestic maupun pasaran mancanegara. Kalimantan Barat khususnya Pulau Lemukutan merupakan salah satu sentra budidaya Eucheuma cottoni dan E.spinosum. Pemanfaatan rumput laut ini sebagai pangan fungsional dalam berbagai macam olahan belum dilaksanakan secara optimal. Kegiatan PKM ini bertujuan untuk memasyarakatkan pemanfaatan dan konsumsi rumput laut serta diversifikasi olahannya dalam usaha untuk meningkatkan system kekebalan tubuh terutama di masa pandemic COVID-19. Sebanyak 256 peserta menyatakan siap hadir di acara webinar yang disampaikan dalam form online yang dibagikan oleh panitia pelaksana kegiatan. Kegiatan sosialisasi dilakukan secara online dengan materi yang disampaikan terkait rumput laut dan aneka olahannya serta fungsinya sebagai bahan pangan dalam meningkatkan derajat kesehatan melalui perbaikan, pemulihan atau peningkatan system kekebalan tubuh, sehingga sangat penting untuk mensosialisasikan konsumsi dan memanfaatkan pangan ini sebagai agen pertahanan tubuh dalam masa pandemic COVID-19. Dari hasil evaluasi kegiatan PKM ini melalui pretest dan post test menunjukkan pengetahuan peserta terkait materi yang disampaikan mengalami peningkatan dari 40-50\% menjadi $80-90 \%$, untuk itu masih diharapkan adanya kegiatan-kegiatan serupa dengan obyek sasaran yang lebih luas dalam wilayah Kalimantan Barat yang dapat meningkatkan kesejahteraan masyarakat pada umumnya.
\end{abstract}

(C) 2020 Author(s).

Keywords: COVID-19, diversification, functional food, immunity, macroalgae. 


\section{Pendahuluan}

Pandemic COVID-19 yang telah melumpuhkan segala sektor kehidupan masyarakat menuntut kita untuk selalu berusaha menjaga daya tahan tubuh, di antaranya adalah dengan konsumsi makanan bergizi. Sejumlah radikal bebas yang terpapar ke dalam tubuh berpotensi menurunkan sistem kekebalan tubuh. Senyawa yang bersifat antioksidan memiliki kemampuan untuk mencegah atau memblok paparan dan produksi radikal bebas secara berlebihan, sehingga dapat mencegah terjadinya kerusakan pada sel imun. Pangan fungsional merupakan pangan atau bahan pangan dengan kandungan senyawa bioaktif yang dapat memberikan manfaat melebihi gizi dasar serta memberikan pengaruh kesehatan dalam pencegahan terhadap suatu penyakit. Alga menjadi salah satu sumber senyawa bioaktif dengan bioaktivitas yang beragam. Senyawa fungsional alga yang telah dimanfaatkan antara lain protein, peptide, asam lemak tak jenuh ganda (PUFAs), polisakarida, pigmen, dan berbagai senyawa aktif yang bersifat sebagai antioksidan, antivirus dan anti-inflamasi. Nutrisi antioksidan yang biasa digunakan yaitu hidrolisat protein, $\beta$-caroten, klorofil, astaxantin, fucoxanthin dan fikosianin serta senyawa golongan polifenol. Senyawa fungsional tersebut dapat diaplikasikan dalam produk pangan fungsional dalam pemeliharaan kesehatan dan pencegahan terhadap suatu penyakit.

Tingginya angka paparan virus Covid-19 baik secara nasional maupun lokal Kalimantan Barat telah menimbulkan kekhawatiran masyarakat berbagai kalangan. Berbagai usaha yang telah dilakukan pemerintah pusat maupun pemerintah provinsi Kalimantan Barat, dari pembatasan sosial berskala besar, pemberlakuan jam lama bagi pemilikpemilik usaha warung kopi, warung makanan yang berpotensi menjadi titik kumpul/keramaian massa digalakkan demi memutus mata rantai penyebaran COVID-19. Semboyan 3M, menjaga jarak, memakai masker dan mencuci tangan dimasyarakatkan lewat penyuluhan massal baik melalui media cetak, media elektronik ataupun petugas lapangan yang siaga turun ke lapangan untuk mengajak masyarakat membudayakan kebiasaan 3M, sebagai langkah preventif untuk meminimalisir resiko paparan covid-19.

Tim pelaksana kegiatan PKM Jurusan Kelautan ikut berpartisipasi dalam memutus mata rantai penyebaran melalui kegiatan webinar dengan topik Sosialisasi Pemanfaatan Rumput Laut dan diversifikasi olahannya sebagai Pangan Fungsional dalam Usaha Meningkatkan Kekebalan Tubuh di Masa Pandemi Covid-19. Tujuannya adalah mensosialisasikan olahan rumput laut dan memasyarakatkan konsumsi pangan hasil laut sebagai usaha untuk meningkatkan system kekebalan tubuh sehingga tidak mudah terinfeksi virus Covid-19. Kegiatan webinar diikuti oleh 150 peserta dari siswa-siswa dan guru pendamping perwakilan SMU SeKota Pontianak, sebagai mitra kegiatan webinar ini.

\section{Metode / Methods}

Kegiatan PKM ini adalah salah satu tri darma perguruan tinggi, yaitu darma ketiga, pengabdian kepada masyarakat sebagai wadah untuk mendeseminasikan hasil penelitian kepada masyarakat sehingga dapat bermanfaat nyata bagi kehidupan masyarakat. Karena masih dalam suasana wabah Covid-19, maka kegiatan dilakukan secara online (webinar). Kegiatan ini disupport oleh Dana DIPA Universitas Tanjungpura Pontianak Kalimantan Barat, dan melibatkan kerja sama institusi antara PTN UNTAN dalam hal ini Tim Dosen Jurusan Ilmu Kelautan sebagai pelaksana Kegiatan dengan Dinas Pendidikan Kota Pontianak. Peserta kegiatan adalah Siswa-siswa perwakilan dari SMU seKota Pontianak, yang diharapkan dapat menjadi perpanjangan tangan dalam menyebarluaskan informasi tentang pemanfaatan rumput laut dalam berbagai jenis olahannya sebagai pangan fungsional untuk meningkatkan system kekebalan tubuh selama menghadapi wabah Covid-19.

Kegiatan ini dilaksanakan pada tanggal 4 Nopember 2020 dengan terlebih dahulu melakukan rapat konsolidasi tim pelaksana dan koordinasi dengan sekolah SMU yang ada di Pontianak. Keikutsertaan siswa SMU dinyatakan dalam

\footnotetext{
* Corresponding author: Dzul Fadly

E-mail address: dzul.fadly@faperta.untan.ac.id
} 
form kehadiran di link google yang dibagikan kepada calon peserta, dan terdaftar sebanyak 256 peserta bersedia hadir, dan pada hari H kegiatan webinar dihadiri 150 peserta.

Pelaksanaan kegiatan berupa ceramah tentang pangan fungsional dari laut beserta beberapa olahannya yang sangat penting untuk dikonsumsi dalam rangka meningkatkan system pertahanan tubuh sehingga tidak mudah diserang oleh penyakit infeksi, khususnya virus Covid-19.

Evaluasi kegiatan diukur berdasarkan peningkatan pemahaman peserta terkait materi pangan fungsional dari rumput laut dan olahannya yang diberikan sebelum dan setelah penyampaian materi oleh speaker.

\section{Hasil dan Diskusi atau Penamaan lainnya}

Sejak Desember 2019 sampai saat ini, masyarakat dunia termasuk masyarakat Indonesia mengalami pandemi COVID-19, penyakit yang disebabkan oleh virus corona SARS-CoV-2. Kalimantan Barat sebagai salah satu wilayah yang berbatasan darat dengan Negara Malaysia, tak luput dari wabah ini, dan sangat berdampak buruk pada kesehatan dan kesejahteraan masyarakat. Terhitung per Desember 2020, pasien terpapar virus Covid-19 di Indonesia sebanyak 743.198 orang (BPS Nasional, 2020) dan khusus di Kalimantan Barat pada rentang waktu yang sama menunjukkan data pasien terinfeksi covid-19 adalah sebesar 2.461 orang (BPS Kalimantan Barat, 2020).

Pembatasan wilayah antar Negara dan antar kabupaten atau wilayah baik berdasarkan kebijakan Pemerintah Pusat maupun peraturan Gubernur Kalimantan Barat dari bulan April 2020, yang dikenal dengan Pembatasan Sosial Berskala Besar (PSBB) sebagai usaha untuk memutus mata rantai penyebaran COVID-19, telah menurunkan pertumbuhan perekonomian nasional (BPS, 2020). Dampak ini terasa juga di daerah yang ditunjukkan pada penurunan daya beli masyarakat. Efek ini secara langsung akan mempengaruhi pola makan masyarakat dan sementara di sisi lain mewabahnya COVID-19 ini menuntut kita untuk meningkatkan kekebalan imunitas tubuh kita terhadap serangan virus melalui konsumsi pangan yang memiliki nilai gizi tinggi dan aktivitas yang dapat menurunkan resiko terjangkitnya penyakit.

Materi yang disampaikan adalah bagaimana kandungan Rumput Laut, bagaimana pengolahannya serta manfaatnya dalam kesehatan tubuh, terutama yang berhubungan dengan system kekebalan tubuh sehingga tubuh memiliki system imunitas yang kuat dan dapat mencegah terjangkitnya penyakit COVID-19.

Nilai gizi yang terkandung dalam produk makanan baik olahan maupun segar adalah faktor penting yang berkontribusi dalam sistem kekebalan tubuh. Dengan mengkonsumsi zat gizi makro maupun mikro yang cukup tersedia dalam bahan makanan dapat mengaktifkan dan meningkatkan sistem kekebalan tubuh (Virralluel-Lopez et al. 2017). Pangan fungsional sangat penting dikonsumsi baik secaa rutin ataupun periodic dengan tujuan meningkatkan derajat kesehatan serta usaha pencegahan penyakit tertentu. Pangan fungsional adalah pangan dengan kandungan senyawa aktif yang bermanfaat terhadap pencapaian kesehatan yang optimal dan amengurangi resiko terpapar penyakit (Mosca et al. 2015; Maina, 2018).

Rumput laut adalah salah satu organisme laut dengan komposisi senyawa aktif yang kompleks, menghasilkan metabolit sekunder dan aktivitas yang beragam dan berpotensi diformulasi sebagai pangan fungsional (Munir et al. 2013). Rumput laut sebagai kelompok organisme makro dengan keanekaragaman spesiesnya, tumbuh di lingkungan perairan laut dan dalam siklus hidupnya adalah mengubah karbondioksida dan mineral melalui proses fotosintesis menjadi suatu biomassa, walaupun beberapa spesies diantaranya bersifat heterotrof. Rumput laut dikenal sebagai makroalga, berbeda dengan mikroalga, berdasarkan, dinding sel, karakteristik dan morfologi selnya, serta pigmen dan cadangan makanan yang dihasilkan (Villarruel-Lopez et al. 2017).

Rumput laut memiliki kandungan protein yang berbeda antara jenis yang satu dengan lainnya, berkisar antara 5-47\%. Kandungan rumput laut tertinggi terdapat dalam rumput laut merah kemudian diikuti oleh rumput laut hijau dan rumput laut coklat (Cerna, 2011). Selanjutnya pada mikroalga Spirulina memilki kandungan protein yang sangat besar yaitu sekitar 76,65\% (Seghiri et al. 2019). Protein yang dihasilkan oleh mikroalga memiliki kualitas nutrisi dan sifat fungsional yang cukup tinggi. Dinding sel pada mikroalga akan melindungi denaturasi protein (Sahni et al. 2019). 
Lemak total dalam rumput laut berada pada kisaran 0,60\% hingga 4,14\% (El-Maghraby and Fakhty, 2015; Rodrigues et al. 2015). Senyawa EPA dan DHA dari mikroalga sangat memenuhi syarat untuk memenuhi nutrisi bayi dan balita dalam masa pertumbuhan serta perkembangan. Lemak yang dikandung oleh rumput laut menunjukkan nilai kalori dan kolesterol yang rendah (Sahni et al. 2019). Pada umumnya, lemak pada rumput laut didominasi oleh sam lemak tak jenuh tunggal (PUFA), sebanyak lebih dari separoh lemak total pada rumput laut dan mikroalga. Asam lemak yang umum terdapat dalam rumput laut dan alga yaitu asam linoleate dan arakidonat (Bellattamania et al. 2018). Rumput laut adalah sumber lemak pada produk pangan fungsional dengan rasio antara omega 6 : omega 3 yang rendah (Biancarosa et al. 2018). Asam lemak omega 3 berperan aktif dalam pengaturan sistem kekebalan tubuh. Rumput laut juga sebagai sumber polisakarida dengan kandungan berkisar antara 40-65\% (Meillisa et al. 2015). Polisakarida tersebut terdiri dari hidrokoloid penyusun dinding sel dan matrik antar sel (Santi et al. 2012). Agar, alginate dan karagenan merupakan jenis polisakarida yang komersil dan telah diperdagangkan luas sebagai bahan baku industry makanan dan obat-obatan. Senyawa-senyawa yang tergolong dalam polisakarida bernilai ekonomi yang sangat tinggi adalah golongan fitokoloid (agar, alginat dan karaginan) serta polisakarida sulfat (laminarin, fucoidan, fucan, mannitol dan ulvan) (Holdt and Kraan, 2011., Villarruel-Lopez et al. 2017). Di sisi lain, polisakarida dari mikroalga memiliki nilai fungsional sebagai prebiotic dan antioksidan, untuk itu rumput laut dan mikroalga ini dapat dimanfaatkan produk pangan fungsional (Pierre et al. 2019).

Kandungan mineral dalam rumput laut dam mikroalga juga sangat penting untuk dikonsumsi karena dapat berperan mengatur poses metabolisme tubuh, seperti Na, K, Ca dan Mg. Mineral-mineral ini ditemukan dalam jumlah yang cukup tinggi secara efisien dapat digunakan sebagai bahan pangan fungsional (Kumar et al. 2011). Kandungan vitaminnya berperan dalam peningkatan kesehatan, sebagai prekursor enzim atau katalis yang dibutuhkan dalam proses metabolisme. Mikroalga menjadi sumber vitamin seperti pro-vitamin A (carotene, apokarotenoid), vitamin C (asam askorbat), vitamin $\mathrm{E}$ (tocoferol dan tocotrienol) dan beberapa kelompok dari vitamin B, seperti B1 (tiamin), B2 (Riboflavin), B3 (niacin) dan B12 (cobalamin) serta vitamin D, yang menunjukan aktivitas antioksidan yang kuat. (Galasso et al. 2019; Japelt and Jacobsen, 2013). Makroalga dan mikroalga laut memiliki potensi yang kuat sebagai antiosidan alami dengan mekanisme aktivitas sebagai penangkap (scavenger) elekron. S Beberapa senyawa antioksidan pada alga merah dan coklat antara lain adalah polifenol, flavonol dan phlorotanin (Zakaria et al. 2011, Sanger et al. 2018). Hidrokoloid yang dihasilkan oleh rumput laut juga memiliki potensi dalam meningkatkan daya lepas zat aktif dan daya serap produk farmasi (Herawati, 2018).

Senyawa fungsional yang terdapat dalam setiap makroalga berbeda-beda antara jenis satu dengan lainnya, seperti alga merah didominasi oleh senyawa aktif antioksidan jenis antheraxanthin (karotenoid), phikoeritrin (pigmen bikobilin), galaktan dan sulfat galaktan (Christaki et al. 2013; Guedes et al. 2011). , alga hijau seperti Halimeda sp. mengandung katekhin (polifenol) dan alga cokelat umumnya mengandung fukosantin dan phlorotannin serta polisakarida sulfat bersifat antioksidan kuat yang mempertahankan berbagai sel kekebalan, sehingga berefek pada respon imun tubuh. Makroalga cokelat Sargassum sp. mengandung asam askorbat dan senyawa aktif, sedangkan $S$. fillipendula didominasi oleh karotenoid dan asam benzena dikarboksil (Pereira et al. 2012).

Rumput laut menghasilkan sejumlah bahan aktif yang penting dan dapat ditambahkan ke dalam makanan konsumsi harian seperti roti, sereal, makanan penutup, es krim, pasta, emulsi dapat bermanfaat untuk kesehatan manusia serta meminimalisir resiko penyakit kronis (Ranga and Ravishankar, 2018). Rumput laut adalah biota laut sumber senyawa polifenol yang aktivitas antioksidannya tergolong kuat (Fernando et al. 2016). Senyawa antioksidan dari rumput laut telah berkembang pesat dan telah banyak digunakan sebagai bahan pangan fungsional (Munir et al. 2013; Daud et al. 2013). Senyawa antioksidan yang umumnya ditambahkan ke dalam makanan adalah seperti $\beta$-caroten dan vitamin $C$ ataupun vitamin E secara aktif dapat meningkatkan fungsi kekebalan tubuh yang berperan dalam perlindungan penting dalam infeksi yang disebabkan oleh bakteri, virus dan parasit (Puertollano et al. 2011). Dengan potensi antioksidan yang besar dalam kandungan rumput laut, maka komoditas ini dapat diaplikasikan dalam produk pangan fungsional dan trend pengembangan produk rumput laut ini memiliki peluang bisnis yang menjanjikan di masa yang akan datang.

Firdaus, (2013) menjelaskan bahwa kandungan senyawa antioksidan pada rumput laut telah digunakan sebagai sumber nutraseutical. Yang secara signifikan akan meningkatkan nilai tambah dari rumput laut di samping fungsinya 
dalam meningkatkan kesehatan. Pengembangan dan penganekaragaman produk oalahan pangan fungsional berbasis rumput laut akan memberikan akses kepada masyarakat dalam usaha penyediaan pangan sehat dengan harga terjangkau baik untuk kebutuhan pangan sendiri ataupun untuk dikomersilkan (Erniati et al. 2016). Pengolahan rumput laut menjadi produk olahan yang memiliki nilai tambah dan nilai ekonomi tinggi. Salah satunya dengan mengolah rumput laut menjadi selai. Selai merupakan produk semibasah yang umumnya diolah dari buah-buahan yang dihancurkan dan dimasak sampai berbentuk setengah padat (Margono, et al., 1993) Rumput laut, dengan kandungan polisakaridanya yang cukup besar merupakan bahan yang potensial sebagai sumber serat pangan (Dwiyitno, 2011), sehingga sangat cocok jika diolah menjadi selai.

Rumput laut dengan kandungan asam lemak tak jenuh ganda (PUFA, omega 3 dan omega 6), beberapa asam amino esensial seperti Leusin, isoleusin dan valin, serta pigmen lutein dan $\beta$-karoten juga vitamin (Vitamin B12) telah direkomendasikan untuk ditambahkan dalam tepung terigu untuk menghasilkan pasta serta produk olahan lain yang dapat digunakan sebagai suplemen dalam produk susu, seperti susu bayi yang saat ini pada umumnya masih menggunakan kedelai sebagai bahan utamanya (Wells et al. 2017). Peranan senyawa bioaktif dari rumput laut ini adalah sebagai efek sinergisme yang menguntungkan terhadap kesehatan (Smerilli et al. 2017; Hamed et al. 2015).

Tabel 1 dan table 2 menunjukkan beberapa produk olahan pangan fungsional berbasis rumput laut makroalga dan mikroalga.

Tabel 1. Aplikasi senyawa fungsional dari makroalga pada produk pangan

\begin{tabular}{|c|c|c|c|c|}
\hline Spesies Makroalga & $\begin{array}{c}\text { Senyawa } \\
\text { Fungsional }\end{array}$ & $\begin{array}{l}\text { Pemanfaatan pada } \\
\text { Produk Pangan }\end{array}$ & $\begin{array}{c}\text { Tujuan } \\
\text { Penggunaan }\end{array}$ & Referensi \\
\hline Caulerpa racemosa & $\begin{array}{l}\text { Fenol, klorofil, } \\
\text { protein, serat }\end{array}$ & Biscuit & $\begin{array}{l}\text { Antioksidan dan } \\
\text { suplemen }\end{array}$ & Kumar et al. 2018 \\
\hline Ulva intestinalis & Klorofil, fenol & Surimi & Antioksidan & $\begin{array}{l}\text { Jannat-Alipour et } \\
\text { al. } 2019\end{array}$ \\
\hline $\begin{array}{l}\text { Kappaphycus } \\
\text { alvarezi }\end{array}$ & Powder seaweed & Sosis & Antioksidan & Pindi et al. 2017 \\
\hline Sagassum wightii & Powder seaweed & Dendeng tuna & Antioksidan & $\begin{array}{l}\text { Hanjaban et al. } \\
2016\end{array}$ \\
\hline $\begin{array}{l}\text { Treptacantha } \\
\text { barbata }\end{array}$ & Fukosantin & Sosis & Antioksidan & Sellimi et al. 2018 \\
\hline Porphyra & $\begin{array}{l}\text { Gliserol } \\
\text { galaktosida }\end{array}$ & Nori & Suplemen & $\begin{array}{l}\text { Admassu et al. } \\
2018\end{array}$ \\
\hline $\begin{array}{l}\text { Undaria } \\
\text { pinnatifida }\end{array}$ & Fukosantin & Wakame & Antioksidan & $\begin{array}{l}\text { Sugimura et al. } \\
2012\end{array}$ \\
\hline $\begin{array}{l}\text { Laminaria } \\
\text { japonica }\end{array}$ & $\begin{array}{l}\beta \text {-karoten, } \\
\text { fukosantin }\end{array}$ & Kombu & Antioksidan & Amorim et al. 2012 \\
\hline Palmaria palmata & Protein, Fenol & Roti & Antioxidant & Allsopp et al. 2015 \\
\hline
\end{tabular}

Evaluasi dari materi yang disampaikan dilakukan dengan melihat hasil pretest dan posttest yang dibagikan kepada peserta di awal dan di akhir acara webinar. Dari 150 peserta yang hadir sebanyak 100 orang di antaranya menyampaikan jawaban pretest dan posttest. Evaluasi kegiatan ini menunjukkan bahwa terjadi peningkatan pengetahuan peserta terkait materi yang disampaikan dari 30-40\% menjadi 80-90\%. 
Tabel 2. Aplikasi senyawa fungsional mikroalga pada produk pangan

\begin{tabular}{|c|c|c|c|c|}
\hline Spesies Mikroalga & $\begin{array}{c}\text { Senyawa } \\
\text { Fungsional }\end{array}$ & $\begin{array}{c}\text { Pemanfaatan pada } \\
\text { Produk Pangan }\end{array}$ & $\begin{array}{c}\text { Tujuan } \\
\text { Penggunaan }\end{array}$ & Referensi \\
\hline \multirow[t]{6}{*}{ Spinulina platensis } & $\mathrm{n}-3$ PUFA & Susu & Suplemen & Poti at al. 2015 \\
\hline & Protein, mineral & Yogurt & Suplemen & Debbabi et al. 2019 \\
\hline & Fikosianin & Biscuit & Antioksidan & El-Baky et al. 2015 \\
\hline & Fenol & Roti/kue & Antioksidan & Marco et al. 2014 \\
\hline & Fikosianin & Permen jelly & Antioksidan & Dewi et al. 2018 \\
\hline & $\begin{array}{l}\beta \text {-karoten dan } \\
\text { protein }\end{array}$ & Mie kering & Suplemen & $\begin{array}{l}\text { Agustini et al. } \\
2017\end{array}$ \\
\hline Dunaliella salina & $\begin{array}{l}\text { Protein, mineral } \\
\text { dan klorofil }\end{array}$ & Pasta & Suplemen & El-Baz et al. 2017 \\
\hline \multirow[t]{2}{*}{ Cholera sp. } & Fenol & Kue & $\begin{array}{l}\text { Aktivitas } \\
\text { antioksidan }\end{array}$ & Batista et al. 2017 \\
\hline & Protein, vitamin & Yogurt & Suplemen & Cho et al. 2004 \\
\hline Tetraselmis suecica & Fenol & Biscuit & $\begin{array}{l}\text { Aktivitas } \\
\text { antioksidan }\end{array}$ & Batista et al. 2017 \\
\hline $\begin{array}{l}\text { Haematococcus } \\
\text { phnvialis }\end{array}$ & Astaxantin & Kue & Antioksidan & Hossain et al. 2017 \\
\hline
\end{tabular}

Tabel 3. Hasil kuisioner peserta pelatihan Webinar

\begin{tabular}{|c|c|c|c|c|c|}
\hline \multirow[t]{2}{*}{ No } & \multirow[t]{2}{*}{ Pertanyaan } & \multicolumn{2}{|c|}{ Kuesioner (pre test) } & \multicolumn{2}{|c|}{ Kuesioner (post test) } \\
\hline & & Ya & Tidak & Ya & Tidak \\
\hline 1 & $\begin{array}{l}\text { Apakah anda pernah mendengar } \\
\text { tentang pangan fungsional? }\end{array}$ & $40 \%$ & $60 \%$ & $100 \%$ & - \\
\hline 2 & $\begin{array}{l}\text { Apakah anda memahami bahwa } \\
\text { rumput laut dan sumber pangan lain } \\
\text { yang berasal dari laut sangat kaya } \\
\text { dengan senyawa bioaktif? }\end{array}$ & $30 \%$ & $70 \%$ & $90 \%$ & 10 \\
\hline 3 & $\begin{array}{l}\text { Apakah anda mengetahui bahwa } \\
\text { rumput kaya dengan kandungan } \\
\text { protein, asam amino sistin dan } \\
\text { metionin, serta asam lemak omega } 3 \\
\text { dan omega } 6 \text { ? }\end{array}$ & $40 \%$ & $60 \%$ & $90 \%$ & $10 \%$ \\
\hline 4 & $\begin{array}{l}\text { Apakah anda familiar mengkonsumsi } \\
\text { rumput laut dalam menu makanan di } \\
\text { rumah? }\end{array}$ & $40 \%$ & $60 \%$ & $50 \%$ & $50 \%$ \\
\hline 5 & $\begin{array}{l}\text { Apakah anda mengetahui bahwa } \\
\text { kandungan aktif dari rumput laut dapat } \\
\text { meningkatkan system imunitas tubuh } \\
\text { sehingga tidak mudah terserang } \\
\text { penyakit? }\end{array}$ & $40 \%$ & $60 \%$ & $90 \%$ & 10 \\
\hline 6 & $\begin{array}{l}\text { Apakah anda mengetahui bahwa } \\
\text { dengan mengkonsumsi rumput laut } \\
\text { akan dapat melindungi tubuh kita dari }\end{array}$ & $40 \%$ & $60 \%$ & $90 \%$ & 10 \\
\hline
\end{tabular}




\begin{tabular}{llllll}
\hline No & Pertanyaan & \multicolumn{2}{c}{ Kuesioner (pre test) } & \multicolumn{2}{c}{ Kuesioner (post test) } \\
\cline { 3 - 6 } & & Ya & Tidak & Ya & Tidak \\
\hline \multirow{2}{*}{7} & $\begin{array}{l}\text { terjangkitnya wabah COVID-19? } \\
\text { Apakah kegiatan pelatihan ini dapat } \\
\text { meningkatkan pengetahuan anda } \\
\text { tentang pangan fungsional dari laut? }\end{array}$ & $70 \%$ & $30 \%$ & $100 \%$ & - \\
\hline
\end{tabular}

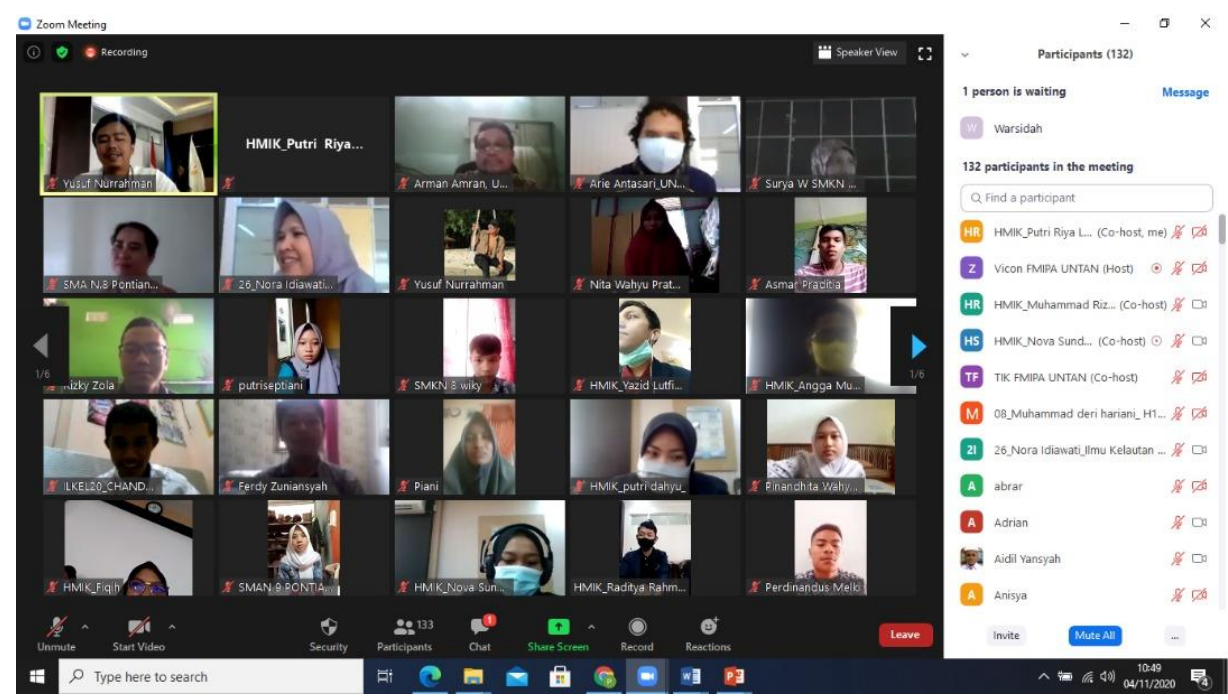

Fig. 1. Dokumentasi kegiatan Webinar tgl 4 Nopember 2020

\section{Kesimpulan}

Dari hasil kegiatan sosialisasi menunjukkan pengetahuan peserta tentang rumput laut dan manfaat serta kandungannya terhadap kesehatan masih sangat kurang yaitu bekisar antara 30-40\% dan terjadinya peningkatan kemampuan menjadi 80-90\%, untuk itu masih perlunya dilakukan pelatihan secara offline untuk meningkatkan pengetahuan masyarakat dalam mengolah dan memanfaatkan rumput laut sebagai pangan rutin untuk tujuan meningkatkan system kekebalan tubuh. Kegiatan ini sebagai bukti sinergitas antara perguruan tinggi dengan stakeholder dalam hal ini adalah siswa sekolah SMU beserta guru pendamping masing-masing.

\section{Acknowledgements}

Terimakasih kepada Bapak REKTOR Universitas Tanjungpura dan Dekan FMIPA Universitas Tanjungpura atas terselenggaranya kegiatan PKM ini yang didanai oleh DANA DIPA UNTAN Tahun Anggaran 2020.

\section{References}

Belattmania Z, Engelen A, Pereira H, Serrao E, Custódio L, Varela J, Zrid R, Reani A, Sabour B. 2018. Fatty acid composition and nutraceutical perspectives of brown seaweeds from the Atlantic coast of Morocco. International Food Research Journal. 25: 1520-1527. 
Biancarosa I, Belghit I, Bruckner CG, Liland NS, Waagbø R, Amlund H, Heesch S, Lock EJ. 2018. Chemical characterization of 21 species of marine macroalgae common in Norwegian waters: benefits of and limitations to their potential use in food and feed. Journal of the Science of Food and Agriculture. 98: 2035-2042.

BPS, 2020, Kalimantan Barat dalam Angka.

BPS, 2020,

Černá M. 2011. Seaweed proteins and amino acids as nutraceuticals. In: Advances in food and nutrition research (Ed. by S.-K. Kim), Academic Press, San Diego, California, USA. pp. 297-312.

Christaki E, Bonos E, Gianennas I, Paneri PCF. 2013. Functional porperties of carotenoids originating from algae. Journal of the Science of Food and Agriculture. 93(1): 5-11.

Daud NA, Babji AS ,Yosup SM. 2013. Antioxidant activity of red tilapia (Oreochromis niloticus) protein hidrolysates as influenced by thermolysin and alcalase. AIP Conference Proceeding. 1571(1): 687-691.

Dwiyitno, 2011. Rumput Laut sebagai Sumber Serat Pangan Potensial. Jurnal Squalen Vol. 6 Nomor 1. https://www.researchgate.net/profile/Dwiy itno_Dwiyitno_/publication/303381338_Se aweed_as_a_potential_source_of_dietary_fiber/links $1573 \mathrm{f} 2 \mathrm{~b} 0608 \mathrm{ae} 9 \mathrm{ace} 84133 \mathrm{ebe} / \mathrm{Se}$ aweed-as-a-potentialsource-of-dietaryfiber. pdf. Diakses 41 April 2020.

El Maghraby DM, Fakhry EM. 2015. Lipid content and fatty acid composition of Mediterranean macroalgae as dynamic factors for biodiesel production. Oceanologia 57: 86-92.

Erniati, Zakaria FR, Prangdimurti E dan Aawiyah DR. 2016. Potensi Rumput laut: Kajian komponen bioaktif dan pemanfaatannya sebagai pangan fungsional. Acta Aquatica. 3(1): 12-17.

Fernando LPS, Kim M, Son KT, Jeong Y, Jeoang YJ. 2016. Antioxidant activity of marine algal polyphenolic compounds: a mechanistic approach. Journal of Medicinal Food. 19(7): 1-14.

Firdaus M. 2013. Indeks aktivitas antioksidan ekstrak rumput laut cokelat (Sargassum aquifolium). Jurnal Pengolahan Hasil Perikanan Indonesia. 16(10): 42-47.

Galasso C, Gentile A, Orefis I, Ianora A, Bruno A, Noonan DM, Sansone C, Albini A, Brunet C. 2019. Microalgae derivates as potential nutraceuticals and food supplements for human health: A Focus on cancer prevention and interception. Nutrients. 11(6): 1226

Guedes AC, Amaro HM and Malcata FX. 2011. Microalga as sources of carotenoids. Marine Drugs. 9(4): 625-644. Hajian S. 2014. Positive effect of antioxidants on immune system. Immunopathologia Persa. 1(1):1-2.

Hamed I, Ozogul F, Ozogul Y, Regenstein JM. 2015. Marine bioactive compounds and their health benefits: A review. Comprehensive Reviews in food science and food safety. 00: 1-20.

Hejazian SR, Takami SZH, Shendi EG. 2016. Sensorial properties, chemical characteristics and fatty acids profile of cheese fortified by encapsulated kilka fish oil. Modern Applied Science. 3: 208-213.

Herawati H. 2018. Potensi hidrokoloid sebagai bahan tambahan pada produk pangan dan non pangan bermutu. Jurnal Litbang pertanian. 37(1): 17-25.

Holdt SL, Kraan S. 2011. Bioactive compounds in seaweed: functional food applications and legislation. J Appl Phycol. 23:543-597.

Jäpelt RB, Jakobsen J. 2013. Vitamin D in plants: a review of occurrence, analysis, and biosynthesis. Frontiers in Plant Science .4: 136

Kumar M, Kumari P, Trivedi N and Shukla MK. 2011. Minerals, PUFAs and Antioxidant Properties of some tropical seaweeds from saurastra coast of India. Journal of Applied Phycology. 23(5): 797-810.

Margono, T., D. Suryati \& S. Hartinah. 1993. Buku Panduan Teknologi Pangan. Kantor Deputi Menegristek Bidang Pendayagunaan dan Pemasyarakatan Iptek,

Maina JW. 2018. Analysis of the factors that determine food acceptability. The Pharma Innovation Journal. 7(5): 253257. 1

Meillisa A, Woo HC, Chun BS. 2015. Production of monosaccharides and bio-active compounds derived from marine polysaccharides using subcritical water hydrolysis. J Food Chem. 171: 70-77.

Mosca AC, Van DVF, Bult JH, Boekel MA, Stieger M. 2015. Taste enhancement in food gels: Effect of fracture properties on oral breakdown, bolus formation and sweetness intensity. Food Hydrocolloids. 43:794-802.

Munir N, Sharif N, Naz S, Manzoor F. 2013. Algae: A potent antioxidant source. Sky journal of Microbiology Research. 1(3): 22-31. 
Pereira H, Barreira L, Figueiredo F, Custodio L, Vizetto-Duarte C, Polo C, Resek E, Angelen A, Varela J. 2012. Polyunsaturated fatty acids of marine macroalgae: potential for nutritional and pharmaceutical applications. Marine Drugs. 10: 1920- 1935. Perikanan Indonesia. 16(10): $42-47$.

Pierre G, Delattre C, Dubessay P, Jubeau S, Vialleix C, Cadoret JP, Probert I, Michaud P. 2019. Whats is in store for EPS Microalgae in the next decade. Molecules. 24: 1-25.

Puertollano MA, Puertollno E, Cienfuegos GA, Pabro MA. 2011. Dietary antioxidants: immunity and host defense. Current Topics in Medicinal Chemistry. 11(14):1752-1766. Ranga RA and Rravishankar GA. 2018. Algae as source of functional ingredients for health benefit. Agriculture Research and Technology. 14(2): 51-55.

Rodríguez DME, Steffolani ME, Martínez CS, León AE. 2016. Effects of Spirulina biomass on the technological and nutritional quality of bread wheat pasta. J. Food Sci. Technol. 58: 102-108.

Sahni P, Aggarwal P, Sharma S, Singh B. 2019. Nuances of microbial technology in food and nutraceuticals: a review. Nutrition and Food Science. p. 1-20.

Sanger G, Kaseger BE, Rarung LK, Domongilala L. 2018. Potensi beberpa jenis rumput laut sebagai bahan pangan fungsional, sumber pigmen dan antioksidan alami. Jurnal pengolahan hasil perikanan Indonesia. 21(2): 208218.

Santi RA, Sunarti TC, Santoso D, Triwisari DA. 2012. Komposisi kimia dan profil polisakarida rumput laut hijau. J Akuatika. 3(2): 105-114.

Seghiri R, Kharbach M, Essamri A. 2019. Functional composition, nutritional properties, biological activities of Moroccan Spirulina microalga. Jurnal of Food Quality. 2019: 1- 11.

Smerilli A, Orefice, I, Corato F, Olea AG, Ruban AV, Brunet C. 2017. Photoprotective and antioxidant responses to light spectrum and intensity variations in the coastal diatom Skeletonema marinoi. Environmental Mirobiology. 19(2): 1-44.

Virralluel-lopez A, Ascencio FNK. 2017. Microalga, potential natural functional food source-a Review. Polish Journal of Food and Nutrition Science. 67(4): 251-263.

Wells ML, Potin P, Craigie JS, Raven JA, Merchant SS, Helliwell KE, Smith AG, Camire ME, Brawly SH. 2017. Algae as nutritional and functional food sources: revisiting our understanding. J Appl Phycol. 29: 949-982.

Zakaria NA, Ibrahim D, Sulaiman SF, Supardy NA. 2011. Assesment of antioxidant activity total phenolic content and in vitro toxixity of Malasyan red seaweed Achanthopora spicifera. Journal Chemical Pharmacology. 3(3): 182-191. 